\title{
„Naše učitelka nás naučila vytvářet skupinky rovnoměrně“: sociální inkluze v základní škole
}

\author{
Radek Vorlíček
}

DOI: 10.21104/CL.2018.1.03

"Our teacher taught us to make equal groups": Social Inclusion in Elementary School

\begin{abstract}
The purpose of this article is to analyze interethnic relationships in inclusive elementary schools in Czech Republic. Special attention is paid to the social distance dynamics in the inclusive classroom. The article sheds light on aspects of social inclusion in educational settings. The text illustrates that in the politics of belonging and inclusion there is a connection between the social position of Roma pupils and the teacher's attitude. The article is based on qualitative, inductive, and ethnographic fieldwork. The central method of the fieldwork was observation.
\end{abstract}

Keywords Social inclusion, ethnic minority, interethnic relationships, elementary school, assistant of pedagogue, inclusive education.
Rád bych poděkoval Dr. Tomáši Samkovi, Ing. Petru Bubákovi, šéfredaktorovi Dr. Jiřímu Woitschovi a oběma recenzentům za jejich podnětné komentáře, které výrazným způsobem přispěly k finální podobě tohoto textu.

Contact Mgr. et Mgr. Radek Vorlíček, Ph.D., Katedra sociální pedagogiky, Pedagogická fakulta, Univerzita Hradec Králové, Hradecká 1227, 50003 Hradec Králové, Czech Republic; e-mail: Vorlicek.r@gmail.com.

Jak citovat / How to cite Vorlíček, Radek. (2018). „Naše učitelka nás naučila vytvářet skupinky rovnoměrně": sociální inkluze v základní škole. Český lid 105, 45-65. doi:http://dx.doi.org/10.21104/CL.2018.1.03 


\section{Úvod}

V předkládaném článku se zaměřuji na sociální a interetnické vztahy v inkluzivní základní škole. Zabývám se dynamikou sociální vzdálenosti mezi dětmi a všímám si, jak tato dynamika upevňuje či naopak oslabuje jejich postavení v hierarchii. Popisuji sociální interakce v kolektivu dětí a zaznamenávám kontext, v němž probíhá inkluze těch, kdo jsou vnímáni jako nositelé jiné než dominantní skupinové identity, at' už má povahu spíše etnickou nebo sociálně třídní. Na základě své empirické zkušenosti a důkladné znalosti terénu se snažím odhalit zejména ty aspekty sociálních a interetnických vztahů, které zůstávají skryté pro svoji jednoduchost a každodennost. Zaměřuji se přitom primárně na první vzdělávací stupeň, kde dochází k časté vzájemné a mnohdy specificky podbarvené interakci žáků a žákyň. Z hlediska sociálních vztahů kladu důraz na aspekty kamarádství, koexistence, koheze, kooperace a jejich protiklady.

Terénní výzkum probíhal v Základní škole Karla Hynka Máchy, která se nachází v obci Buková v pohraničním regionu s vysokou nezaměstnaností a migrací. ${ }^{1}$ V obci žije přibližně 1500 obyvatel a v jejím okolí se nachází několik sociálně vyloučených lokalit, ve kterých žije blíže nespecifikovaný počet obyvatel. Tato škola je držitelem titulu „Férová škola“ a je školou inkluzivního typu. ${ }^{2}$ Již řadu let se snaží vzdělávat všechny žáky pohromadě. Mezi 210 žáky, kteří školu navštěvují, je řada dětí se specifickými vzdělávacími potřebami, ze sociálně znevýhodněných rodin, s rozmanitým rodinným zázemím, nadáním a dokonce i s poruchou autistického spektra.

\section{Popis kontextu výzkumu}

Inkluzivní Základní škola Karla Hynka Máchy má jasně formulované vize, cíle a ideály (včetně cest $\mathrm{k}$ jejich dosažení), které vedení proklamuje a za nimiž si stojí, nehledě na kritiku, která se občas ze strany veřejnosti ozývá. Základní škola úzce spolupracuje s místní komunitou. Snaží se získat podporu veřejnosti a překonat nedůvěru části veřejnosti k inkluzivnímu vzdělávání. ${ }^{3}$

1 Název základní školy a lokality je fiktivní - bude vysvětleno dále.

2 Jak Ize rozeznat inkluzivní prostředí? Návod nabízí například

Monika Tannenbergerová (2016: 41-58).

3 Podle reprezentativního sociologického šetření, realizovaného EDUin, o. p. s., v roce 2013, 80 \% populace vyhovuje oddělování dětí do různých vzdělávacích proudů (EDUin, o. p. S., Perfect Crowd 2013). Společná škola pro všechny děti má nižší míru podpory, což je podle výsledků stejného průzkumu zapříčiněno tím, že velká část veřejnosti nevěří, že by stát uměl zorganizovat kvalitní vyučování pro všechny děti v jedné škole (EDUin, o. p. s., Perfect Crowd 2013). Oproti tomu sociologická šetření v letech 2015 a 2016 přinášela zprávy, že česká společnost začíná být více nakloněna myšlenkám inkluzivního vzdělávání. Například podle reprezentativního šetření agentury IPSOS pro Českou odbornou společnost pro inkluzivní vzdělávání o názorech české veřejnosti na společné vzdělávání dětí s různými vzdělávacími potřebami si 57 \% české populace myslí, že inkluze je správná (blíže ČOSIV 2015). 
Vedení školy se snaží budovat inkluzivní prostředí ve škole. ${ }^{4}$ Tím má konkrétně na mysli to, že se snaží zapojit všechny žáky do vzdělávacího procesu a školní komunity, vytvořit přátelské prostředí a klidnou i sdílnou atmosféru ve škole, zkvalitnit proces výuky pro potřeby všech žáků, podporovat nadání žáků a vytvořit jim vhodné podmínky pro jejich individuální rozvoj, podporovat vnitřní motivaci v učení a vést žáky k vzájemné toleranci a ohleduplnosti. Škola chce dát šanci na kvalitní vzdělání všem dětem bez rozdílu. Rozmanitost není vnímána jako překážka, ale jako něco přirozeného (z rozhovoru s ředitelem školy). Důraz je kladen na primární prevenci a předcházení konfliktům. To neznamená, že by se na Základní škole Karla Hynka Máchy konflikty neobjevovaly. Konflikty zde přirozeně vznikají, ale oproti jiným školám je jim věnována větší pozornost ze strany vedení a pedagogického sboru. Škola například začíná den tzv. „třídní patnáctiminutovkou“. Každý běžný vyučovací den začíná setkáním třídních učitelů se svými žáky, které má vést k upevnění vztahu mezi učitelem a žákem a zároveň být preventivním opatřením proti všem možným nepř́ijemnostem školního života.

Základní škola Karla Hynka Máchy se prezentuje navenek jako škola, která neškatulkuje žáky na „úspěšné“ a „neúspěšné“. ${ }^{5}$ Maximálně zdůrazňuje myšlenku, že každý žák by se měl snažit dosáhnout svého maxima a že každý žák může být úspěšný. Na jednu stranu v porovnání s jinými školami, které jsem navštívil v rámci svého výzkumu, se jim tyto myšlenky do velké míry daří uplatňovat v praxi, což má samozřejmě velký dopad na sociální vztahy v kolektivu dětí. Na druhou stranu se část pedagogického sboru s uvedenými myšlenkami neidentifikuje. Podle „opozičních“ učitelů je zvolený přístup školy demotivující (vzdělanostní úroveň se snižuje a žáci se nemusí př́liš snažit, aby na stanovenou lat'ku dosáhli). Z každého žáka se nedostává maximum a individuální plán je mnohým dětem přiřazován zcela zbytečně.

Uvnitř pedagogického sboru Základní školy Karla Hynka Máchy dochází ke skryté i přímé rezistenci vůči vedení a k interpersonálním a ideovým konfliktům, jež ovlivňují celý edukační proces a vzájemnou spolupráci mezi učiteli. ${ }^{6} \mathrm{~V}$ průběhu svého výzkumu jsem si všimnul, že část pedagogů podezř́ívá asistenty, že na ně donášejí (ředitel základní školy tohle tvrzení popírá). Následkem toho se rozhořel konflikt, který měl neblahý vliv na kooperativnost mezi pedagogy a asistenty pedagoga.

4 Škola je zapojena do několika projektů, které se zaměřují na inkluzi, prevenci školní neúspěšnosti znevýhodněných dětí i na posílení spolupráce mezi školou, rodinou a neziskovými organizacemi (názvy projektů z etických důvodů nezmiňuji). Vedení školy je také velice dobře obeznámeno s myšlenkami odborníků na inkluzi - např. Booth a Ainscow (2007) a Svoboda, Říčan, Morvayová a Zilcher (2015).

5 Diskuse o tom, kdo je a není úspěšný, úzce souvisí s konceptem sociální inkluze a exkluze. Institucionální mechanismy, dělící žáky na úspěšné a neúspěšné, mohou podle mého názoru přispívat k sociální roztržce mezi žáky. 
A jak se tento konflikt mezi pedagogy a asistenty pedagoga projevoval v praxi? Dvě školní třídy měly jet společně na školní výlet do zoologické zahrady. Třídní učitelky obou tříd ale nechtěly jet na tento výlet s asistenty pedagoga, a to jak kvůli výše uvedenému podezření z donášení, tak implicitně i kvůli tomu, že nechtěly, aby se výletu zúčastnili žáci s potřebou vyšších podpůrných opatření. Ředitel řešil tento vzniklý konflikt a rozhodl, že je nemyslitelné, aby část žáků byla tímto způsobem vyčleněna z kolektivu (žáci s potřebou vyšších podpůrných opatření by nemohli jet na výlet bez pomoci asistenta). Akce tedy měla pokračovat jak za účasti asistentů, tak všech žáků. Nicméně dvě třídní učitelky bez vědomí ředitele napsaly textové zprávy všem rodičům, že se vybrané peníze za výlet vrací, protože ředitel školní výlet zrušil. Ředitel jejich jednání označil nejen za cílené podkopávání jeho pozice a oslabování autority, ale hlavně za podkopávání ideálů a myšlenek školy.

Pro ředitele jsou na prvním místě žáci. Řídí se heslem: „My jsme tady kvůli žákům. "Všichni žáci, včetně žáků s potřebou vyšších podpůrných opatření, chtěli jet na výlet do zoo, a ředitel jim to chtěl všem umožnit. Jenže někteří učitelé v tom vycítili příležitost, jak dát najevo svůj nesouhlas se směřováním školy a jak hodit řediteli „klacek pod nohy“ (domnívám se, že učitelé přirozeně mohou vést s ředitelem polemiku, ale do polemiky by takto manipulativně neměli zatahovat žáky, protože žáci nemají být nástrojem k dosažení změny v řízení školy).

Konflikt mezi ředitelem a učiteli se podle mého názoru přenáší i na žáky. Žáci sice nerozumějí tomu, v jaké rovině se konflikt mezi ředitelem a učiteli odehrává; možná neumějí tento konflikt pojmenovat slovy, ale rozhodně na ně působí (je pro ně pravděpodobně hůř čitelný, ale ne nevnímatelný). Děti vidí stejný konflikt jako dospělí, ale podstatně z jiného úhlu. Dospělí si myslí, že tomu děti nerozumějí, ale ve skutečnosti takovému konfliktu děti možná rozumějí svým způsobem daleko lépe. Jsem přesvědčen o tom, že by bylo velkou metodologickou chybou podceňovat citlivost a vnímání žáků na to, co se odehrává mezi učiteli uvnitř školního prostředí. Jak uvádím v jiném článku, „z hlediska porozumění a dekódování dětských významů, představ, myšlení a chování, existují určitá analytická rizika, která mohou vznikat tehdy, nepřipouští-li si výzkumník možnost, že dětský svět je specifický a v mnohém odlišný od světa dospělého člověka. Stejná rizika ale mohou vznikat i tehdy, klademe-li příliš velký důraz na odlišnost dětského světa od dospělého“ (Vorlíček 2017a: 28-29).

Tento konflikt zde zmiňuji nejenom proto, že nastiňuje situaci v základní škole, ale i proto, že do jisté míry souvisel s vyjednáváním mé pozice ve škole. V průběhu výzkumu jsem pojal podezření, že část pedagogů byla přede mnou velmi opatrná a vnímala mě jako „instrument of top management” (Bryman 2012: 408). 


\section{Metodologie}

Výzkum v Základní škole Karla Hynka Máchy byl součástí dlouhodobého a širšího výzkumného projektu, který byl realizován v rámci dizertační práce a který celkově probíhal ve dvanácti základních školách v různých českých a slovenských regionech (blíže Vorlíček 2016b; 2017a, b, c, d, e). Dizertační práce se zabývá sociální dynamikou a interetnickými vztahy ve školním prostř̌edí. Jedním z cílů práce bylo zkoumat, jak se v kolektivu dětí na základní škole projevuje dynamika sociální inkluze a exkluze a jak přispívá k hierarchizaci sociálních aktérů. V rámci výzkumu jsem si tak stanovil cíle, ale nestanovil jsem si konkrétní výzkumné otázky, na které bych hledal odpověd'. V tomto ohledu jsem byl ovlivněn přístupem Pražské skupiny školní etnografie (1998: i): „V terénu je třeba hledat nikoli odpovědi na předem připravené otázky, ale vůbec otázky samy. Jen tak se lze dobrat toho, co je podstatné pro dané prostředí, pro jeho aktéry, a vyhnout se neživotným pojednáním o vymyšlených či př́liš obecně pojatých problémech.“

Terénní výzkum dohromady probíhal deset měsíců. Byl realizován v roce 2015 a 2016, tedy v době, kdy v České republice probíhal „boj za inkluzi“ a „boj proti inkluzi“. Výzkum byl kvalitativního typu a opíral se o metodu polozúčastněného pozorování. Z teoreticko-metodologického hlediska byl ukotven v antropologii vzdělávání (např. Spindler 2000; 1963; 1974; Hymes 1980; Mead 1972; Levinson - Pollock 2011). ${ }^{7}$ Jedná se o subdisciplínu sociální antropologie, která se specializuje na vzdělávání, socializaci, vzdělávací instituce a jejich sociokulturní kontext. Mezi oblíbená témata antropologie vzdělávání patří například reprodukce sociálních nerovností, ideologie vzdělávání, interkulturní vzdělávání a soužití, studium školního prostř̌edí, proměny a reformy vzdělávání, sociální a interetnické vztahy, otázka kulturní akvizice, sociální inkluze apod.

Výzkum byl rovněž založen na pomezí komparativní studie a výzkumné strategie „Multi-Sited Ethnography“, která byla rozpracována Georgem Marcusem v 90. letech 20. století (Marcus 1995; 1998). ${ }^{8}$ Ohraničení výzkumu v rámci výzkumné strategie „Multi-Sited Ethnography“ je do jisté míry komplikované a odlišné oproti „tradičním“ etnografickým studiím. Výzkumné pole je rozprostřeno v několika lokalitách a týká se různých sociokulturních a vzdělávacích toků myšlenek, které lokalitami prostupují. V dizertační práci se tak zabývám výzkumem ve dvanácti základních školách, zajímám se více o perspektivu systému než o aktérskou perspektivu a svůj terén do velké míry

7 Antropologie vzdělávání je do jisté míry analogická školní etnografii či etnografii ve vzdělávání (např. Mills - Morton 2013).

8 Výzkumná strategie je uceleně a kriticky rozebrána v knize „Multi-Sited Ethnography“ (Falzon 2009), kde řada odborníků z antropologie, sociologie, geografie či migračních studií prezentuje její teoretické a praktické aspekty v kontextu současných rozmanitých výzkumů. 
vymezuji jako školní tř́du beze zdí. Oproti tomu v tomto článku se výhradně soustředím na dvě školní třídy v konkrétní základní škole. ${ }^{9}$

Během výzkumu v Základní škole Karla Hynka Máchy jsem se maximálně snažil dodržovat standardy ochrany osobnosti těch, s nimiž jsem v terénu spolupracoval (informovanost, anonymita, zodpovědnost, otevřenost, upřímnost, poctivost, důvěryhodnost získaných informací, ochrana důvěrné komunikace, dodržení závazků, nezneužití výsledků). Název školy a lokality je přejmenován. Identita dětí i učitelů byla chráněna během výzkumu i po jeho skončení. Domnívám se, že z důvodu zvýšené ochrany identity školy nemohu otevřeně přiznat všechna specifika školy a lokality. Nemůžu ani otevřeně přiznat kontext minulý i současný, přestože prostředí školy a lokality do jisté míry sleduji i nadále. Pro jistotu dokonce některé (méně podstatné) detaily záměrně pozměňuji natolik, aby školu a lokalitu téměř nebylo možné odhalit. Činím to hlavně z důvodu přesvědčení, že v našem rozhodování o podobě textu musí být upřednostněna etika výzkumu, zejména dodržení závazků s účastníky výzkumu. ${ }^{10}$

Během práce v terénu jsem se snažil klást důraz na etické principy, které jsou formulované v Etickém kodexu České asociace pro sociální antropologii. Řediteli základní školy jsem například pravdivě popsal, co je předmětem mého zájmu zkoumání - přinejmenším v obecné rovině. Jsem přesvědčen, že by bylo neetické, kdybych svůj pravý důvod výzkumu zatajil. „Obecně se antropologové shodují na tom, že by bylo neetické neinformovat hostitele o tom, za jakým cílem antropolog přichází. Zkoumaní lidé musí mít právo odmítnout pozorování, pokud se nechtějí stát předmětem antropologické analýzy. V případě skrytého pozorování jsou o tuto možnost připraveni“ (Eriksen 2008: 41).

\section{K terminologii: Rom/romský žák}

Již delší dobu se setkáváme na odborné, vládní i nevládní úrovni s hledáním romské identity a se snahou vymezit a definovat Romy. Jednotlivé definice jsou mnohdy zavádějící a mají svá úskalí: vymezení romské kultury, (ne)existence romského národa, identifikace na základě jakéhosi typického vzhledu, definice skrze sociální vyloučení, ale všichni Romové nejsou sociálně vyloučeni a v sociálně vyloučených lokalitách nežijí jenom Romové apod. ${ }^{11}$ Vzhledem k tomu, že okolo těchto definic je mnoho sporů, rád bych čtenáři

9 Z hlediska výzkumu vzdělávání je podle Pieridese (2010) „Multi- Sited Ethnography“ užitečná nejméně ve čtyřech oblastech: „... it reconfigures the boundaries of the ethnographic site; it makes it possible to take into account a world that is on the move; it breaks through the critiques of particularism; and, finally, it considers graduate dissertations as a locus of disciplinary influence" (Pierides 2010: 187).

10 Stejným způsobem jsem postupoval i při výzkumu jiných základních škol (viz Vorlíček 2016b).

11 V souvislosti s chápáním Roma na základě jakéhosi typického romského vzhledu Marek Jakoubek (2004) poukazuje, že jakékoliv vymezení Romů, jehož součástí jsou faktory biologické, implicite podporuje rasové smýšlení. 
stručně nastínil, na co jsem v této souvislosti kladl důraz v rámci svého dlouhodobého výzkumného projektu.

V rámci svého výzkumu jsem se většinou nezabýval otázkou původu rodin dětí, přestože jsem si uvědomoval, že pozice, jakou má dítě ve třídě, souvisí s tím, z jaké rodiny pochází, zda je rodina zasažena vyloučením a jaký má postoj ke vzdělávání - viz Bittnerová, Doubek a Levínská (2011), Morvayová (2010), Vorlíček (2016a) a Vorlíček (2017d). Zaměřoval jsem se spíše na etnicitu, která je situovaná a reprodukovaná v rámci lokální společnosti. Nezabýval jsem se proto př́liš diskusí o tom, kdo je a není Rom, protože romství je podle mého názoru komunikováno a vyjednáváno v rámci interakcí v lokální společnosti i škole. Snažím se tím ukázat, že marginalizace může mít mnoho zdrojů, které jsou právě dány mnohovrstevnatostí kontextů, do nichž se dítě dostává, a etnicita je jen jeden parametr (blíže Vorlíček 2017a).12

\section{Sociální inkluze ve druhé třídě}

Sociální inkluzi lépe porozumíme, máme-li (analytickou) zkušenost se sociální exkluzí. Moje zkušenost s exkluzivním prostředím mi pomáhala uvědomovat si prostredí inkluzivní. Myslím si, že tedy v tomto smyslu je podstatné uvědomit si to, co tvrdí Goerge Lakoff (2006: 137): „Naše zkušenost vidění může být do velké míry závislá na tom, co víme o tom, na co se díváme."

Druhou třídu Základní školy Karla Hynka Máchy navštěvuje deset dívek a šest chlapců. Mezi těmito šestnácti dětmi jsou tři romské dívky a jeden romský chlapec. Při svém výzkumu jsem dospěl k jednoznačnému názoru, že ve druhé třídě jsou romští žáci z hlediska každodenních sociálních a symbolických interakcí plně začleněni do kolektivu dětí. Během prováděného výzkumu byla sociální inkluze rozpoznatelná a z mého pohledu čitelná v každodenních rutinních interakcích.

Níže předkládám vybrané a v interakci stále se opakující příklady, na nichž se pokusím vysvětlit, jak fungují sociální vztahy a jak se žáci rozmistují v prostoru školní třídy. Příklady jsou doplněny o grafické ilustrace, jejich cílem je především zvýraznit určité aspekty popisovaného jevu a napomoci percepci jeho některých stránek. Jedná se většinou o (vizuálně zdokonalená)

12 V současné době je pravděpodobně nejrozšířenější definice romského žáka od společnosti Gabal, Analisis \& Consulting (blí̌e GAC 2009: 11). S odlišnou definicí přichází Lábusová, Nikolai, Pekárková a Rendl (2010: 19-21), kteří se odvolávají na historickou zkušenost, sestěhování za př́mé či utajované účasti samospráv do míst "se špatnou adresou" a na adaptaci životních strategií na život v sociálně vyloučeném prostředí; v kontextu českého prostředí je průlomový výzkum bývalého veřejného ochránce práv, který od sebe odlišoval adresný a neadresný sběr etnických dat (viz Varvařovský 2012a; 2012b). Kontroverzní osobou je Jakoubek, který poukazuje, že Romové nemohou být definováni kulturně ani jazykově, nebot́ mezi nimi neexistuje jednotné etnické povědomí a jsou spíše umělým konstruktem majoritní populace (viz Jakoubek 2004). Jakoubka kvůli jednostrannosti a chybějícímu kontextuálnímu pohledu na etnicitu kritizuje Elšík (2005), jenž dodává, že „....pokus o intenzionální definici jakékoli etnické skupiny je možný jen za cenu odhlédnutí od situační dynamiky mezietnické komunikace." 
schémata, která byla zaznamenána v průběhu výzkumu do terénního deníku. ${ }^{13}$ Je třeba mít ale na paměti, že podobně jako terénní poznámky nejsou úplným otiskem reality (viz Emerson - Fretz - Shaw 1995), tak ani grafické ztvárnění není realistické, protože spíše ilustruje výsledek analýzy, než aby přenášelo kreslenou fotodokumentaci mé práce.

V níže uvedených příkladech a následné analýze se opírám o koncept sociální distance. Tento koncept chápu jako interakční přístup, který zkoumá blízkost v interakcích a který mapuje to, co posiluje a redukuje rozdíly v sociální vzdálenosti mezi jednotlivými žáky. ${ }^{14}$ Vycházím přitom výhradně z pozorování, nikoliv z Bogardusovy škály sociální distance (Bogardus 1925; 1933; 1959). ${ }^{15}$ „Sociální distance vyjadřují relační perspektivu nerovností. Ve své odlišnosti nejsme totiž toliko jiní, vždy se lišíme od něčeho či někoho, proto předem nedefinujeme hierarchicky uspořádané skupiny, například pomocí určitého třídního schématu, ale sledujeme vzorce vzájemných vztahů mezi lidmi, které samy o sobě určují povahu stratifikace (Šafr 2008: 12).“

Z hlediska analýzy sociálních interakcí ve školním prostředí si uvědomuji, že sociální vzdálenost může být malá, anebo velká, a že se může odehrávat jak v rovině vertikální, tak v horizontální. Rovněž si uvědomuji další dva základní předpoklady, které přejímá Šafr ze Steinbachové: za prvé, sociální vzdálenost (někdy označovaná též jako mentální) se často prolíná a koreluje se vzdáleností fyzickou (geografická distance); za druhé, sociální vzdálenost může existovat navzdory malé fyzické vzdálenosti (Steinbach 2004: 12).

\section{Přátelství mezi romskými a neromskými žáky}

Žáci druhé třídy měli kamarády mezi romskými i neromskými dětmi. O vyučovacích hodinách i o přestávkách nevytvářeli skupiny romské nebo neromské. Mezi dětmi panovala přátelská atmosféra a zdálo se, že děti žijí ve vzájemné symbióze. Svůj podíl na tom zajisté má třídní učitelka, která tahá za nitky a spektakulárně zmenšuje délku sociální vzdálenosti mezi romskými a neromskými žáky. Posiluje soudržnost školního kolektivu a nabádá žáky k smířlivějším postojům vůči žákům s horšími studijními výsledky. Učí žáky toleranci, která se v konečném důsledku nevztahuje pouze na žáky méně nadané, nýbrž i na žáky, kteří jsou vnímáni jako nositelé jiné než dominantní identity, at' už má povahu spíše etnickou, nebo sociálně třídní.

13 V grafických schématech modrý čtverec znázorňuje chlapce, červený kruh dívky a zelený trojúhelník pedagogy. Za účelem vyšší srozumitelnosti $v$ těchto schématech ještě označuji romské děti indexem $\mathrm{R}$. 
Při matematice učitelka připravuje pro žáky soutěž „vyřazko“. Děti vytvářejí dvojice a učitelka jim zadává př́klady (např́klad $6 \times 4$ ). Postupuje vždy jen ten z dvojice, který jako první vypočítá správně př́klad (žák, který prohraje, je vyřazen a odchází si sednout do lavice). Romská dívka se umístuje na druhém místě, za které je odměněna třemi bonbóny. Jeden si ponechává a o zbylé dva se dělí se svými kamarádkami. Jeden bonbón dostává romská dívka z přední lavice a druhý neromská dívka ze třetí lavice uprostred. (Záznam z pozorování, matematika, druhá třída Základní školy Karla Hynka Máchy, 10. 5. 2016.)

Romský chlapec se kamarádí s chlapcem ze zadní lavice. Při matematice žáci samostatně počítají cvičení číslo tři. Jakmile chlapec ze zadní lavice je hotov s př́kladem, táže se učitelky, zda si může jít sednout k romskému spolužákovi a společně s ním počítat následující cvičení číslo čtyří.

Učitelka souhlasí. (Záznam z pozorování, matematika, druhá tř́ída Základní školy Karla Hynka Máchy, 5. 5. 2016.)

Během vyučovací hodiny českého jazyka je romská dívka ze zadní lavice vyvolána $k$ tabuli. Má doplnit písmeno B nebo P ze závorky u spojení „ZU_(B/P)“. Dívka správně doplňuje písmeno B. Učitelka reaguje na její doplnění a ptá se dívky, z jakého důvodu napsala písmeno B. Dívka vysvětluje př́klad následovně: „Zuby, slyšíme B a píšeme B. “Učitelka souhlasí a dodává, že si může jít sednout. Dívka neodchází nejkratší cestou př́mo do své lavice, ale oklikou. Po cestě si plácne s romskými dívkami v přední lavici vpravo. (Záznam z pozorování, český jazyk, druhá třída Základní školy Karla Hynka Máchy, 11. 5. 2016.)

\section{Vliv třídní učitelky na interakční kulturu v kolektivu dětí}

Učitelka má významný vliv na utváření pozitivního sociálního klimatu školní třídy a zavádí nepsaná pravidla interakce, která výrazně ovlivňují interakční kulturu v kolektivu dětí. Podsouvá dětem inkluzivní myšlenky a vzdělává žáky společně, aniž by to podle mého i jejího názoru znamenalo snížení vzdělávací úrovně. ${ }^{16}$ Učí žáky, co je správné a nesprávné, přičemž do první kategorie víceméně spadají myšlenky inkluze a do druhé kategorie myšlenky

16 Inkluzi ve vzdělávání přibližuje například Monika Tannenbergerová (2016) či Tony Booth a Mel Ainscow (2007), sociální klima školní třídy Jiří Mareš (1998). 
exkluze. ${ }^{17}$ Cíleně a opakovaně vytváří sociální skupinky žáků tak, aby byly rovnoměrně rozloženy $z$ hlediska genderu, etnicity a školní úspěšnosti. ${ }^{18}$ Její důraz na rovnoměrné rozložení je vidět při práci ve skupinkách o vyučovacích hodinách.

O vyučovací hodině českého jazyka třídní učitelka rozdělí žáky do čtyř skupin a následně jim rozdá psací tabule. Žáci mají napsat slova, která jim učitelka přednese. Jejich úkolem je, aby je napsali všechna správně. Učitelka diktuje slova: „mrkev, ořišek, zelenina, židle, keř.“ Žáci si zapisují slova kř́dou na svoji tabuli - viz obrázek 1 Český jazyk a rozdělení žáků podle učitelky. (Záznam z pozorování, český jazyk, druhá třída Základní školy Karla Hynka Máchy, 13. 5. 2016.)

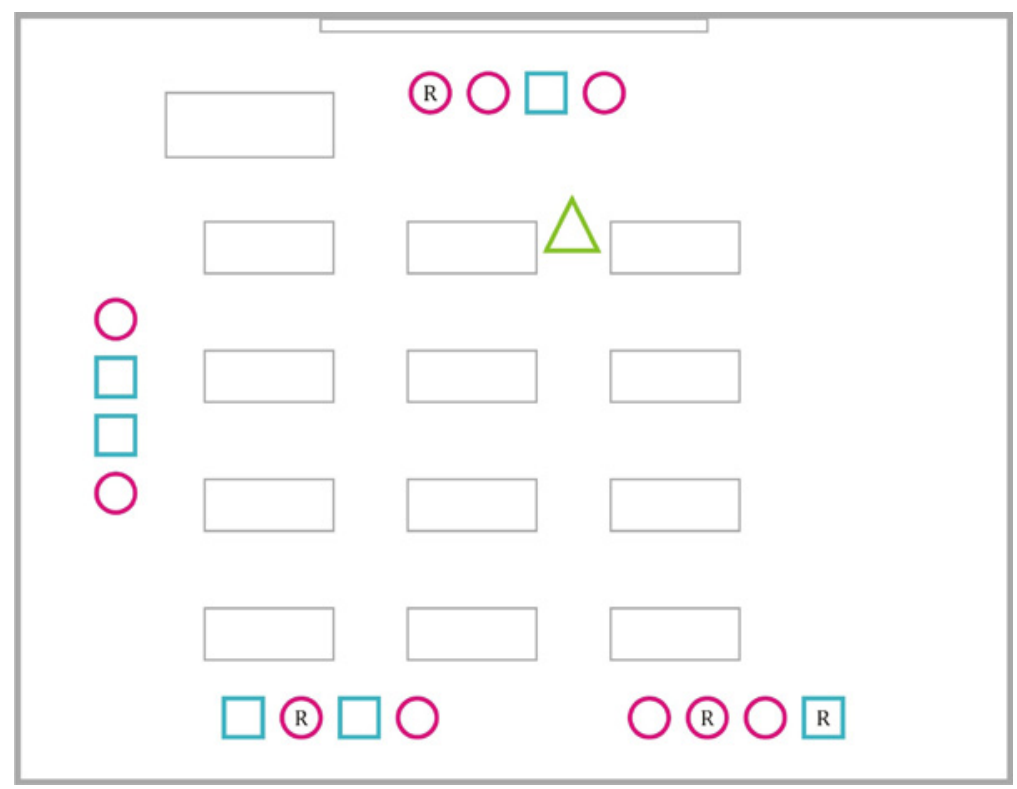

Obrázek 1 Český jazyk a rozdělení žáků podle učitelky

17 Třídní učitelka usměrňuje sociální interakci žáků nejenom svým jednáním o vyučovacích hodinách, ale i stanovením zasedacího pořádku a jasných nepsaných pravidel, jež usměrňují chování žáků. Mezi nepsaná pravidla patří např́ílad zákaz jakéhokoliv posmívání se spolužákům: Při matematice učitelka zadává Kateřině př́iklad „19 - 4“. Kateřina odpoví, že "19-4=16“. Jeden spolužák se lehce zasmál. Učitelka se na něj obrátila se slovy: „Neposmívej se, ty bys brečel, kdyby se ti někdo posmíval. Běž a omluv se Kateřině." Chlapec vstal ze svého místa a za přihližení celé třídy se jí omluvil.

Hájková a Strnadová (2010: 64) vymezují principy inkluzivního pedagoga z hlediska heterogenity pohlaví a genderových aspektů inkluze: „Inkluzivní pedagog přistupuje ke každému žákovi bez ohledu na všeobecná očekávání, která jsou spojována s projevy pohlavních rozdílností. Jeho gendrově otevřený a korektní prístup se projevuje jak v bezprostřední komunikaci s nimi, tak i v zadávání školních úkolů a jejich hodnocení.” 


\section{Rozmistování žáků v prostoru školní třídy}

Analýza sociálních a interetnických vztahů v první třídě Základní školy K. H. Máchy ukazuje, že mezi romskými a neromskými dětmi je malá prostorová i fyzická vzdálenost. Během svého výzkumu jsem nezaznamenal nebo se mi přinejmenším nepodařilo zaznamenat větší sociální vzdálenost mezi těmito dětmi, která by se projevovala v sociální interakci (viz níže uvedené příklady a schémata).

O vyučovací hodině českého jazyka žáci míř́ na koberec a rozmistují se tak, jak je vyobrazeno na níže uvedeném obrázku. Učitelka jim předčíá pohádku... (Záznam z pozorování, český jazyk, druhá třída Základní školy Karla Hynka Máchy, 6. 5. 2016.)

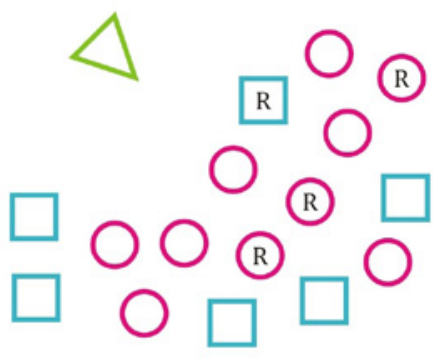

Obrázek 2 Pohádka na koberci

Během matematiky učitelka oznamuje dětem, aby si šly sednout na koberec a poslouchaly čísla, která budou chybět $v$ číselné radě (viz rozmístění žáků na koberci, vyobrazené na obrázku 3 Matematika a číselná řada). Učitelka diktuje čísla „11, 12, 14, 15, 16, 17, 19, 20" a děti přicházejí na to, že v řadě chybí čísla „13 a 18“. (Záznam z pozorování, matematika, druhá třída Základní školy Karla Hynka Máchy, 9. 5. 2016.) 


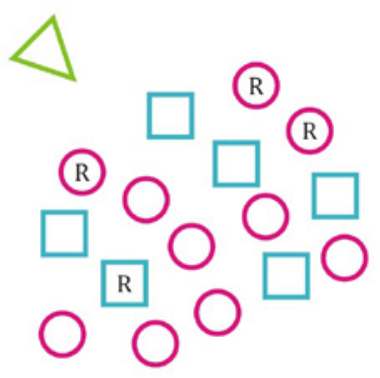

Obrázek 3 Matematika a číselná řada

O vyučovací hodině českého jazyka si děti mají vzít psací tabule, najít si místo na zemi na podlaze a psát malá a velká písmena, která jim učitelka bude diktovat. Děti vytvářejí řadu napravo od stolu třídní učitelky (viz obrázek 4 Český jazyk a psací tabule). Piší velké $a$, velké $v$, malé $l$, malé $y$, malé $b$ a velké $r$. Učitelka kontroluje, zda děti písmena zapsaly správně. (Záznam z pozorování, český jazyk, druhá třída Základní školy Karla Hynka Máchy, 11. 5. 2016.)

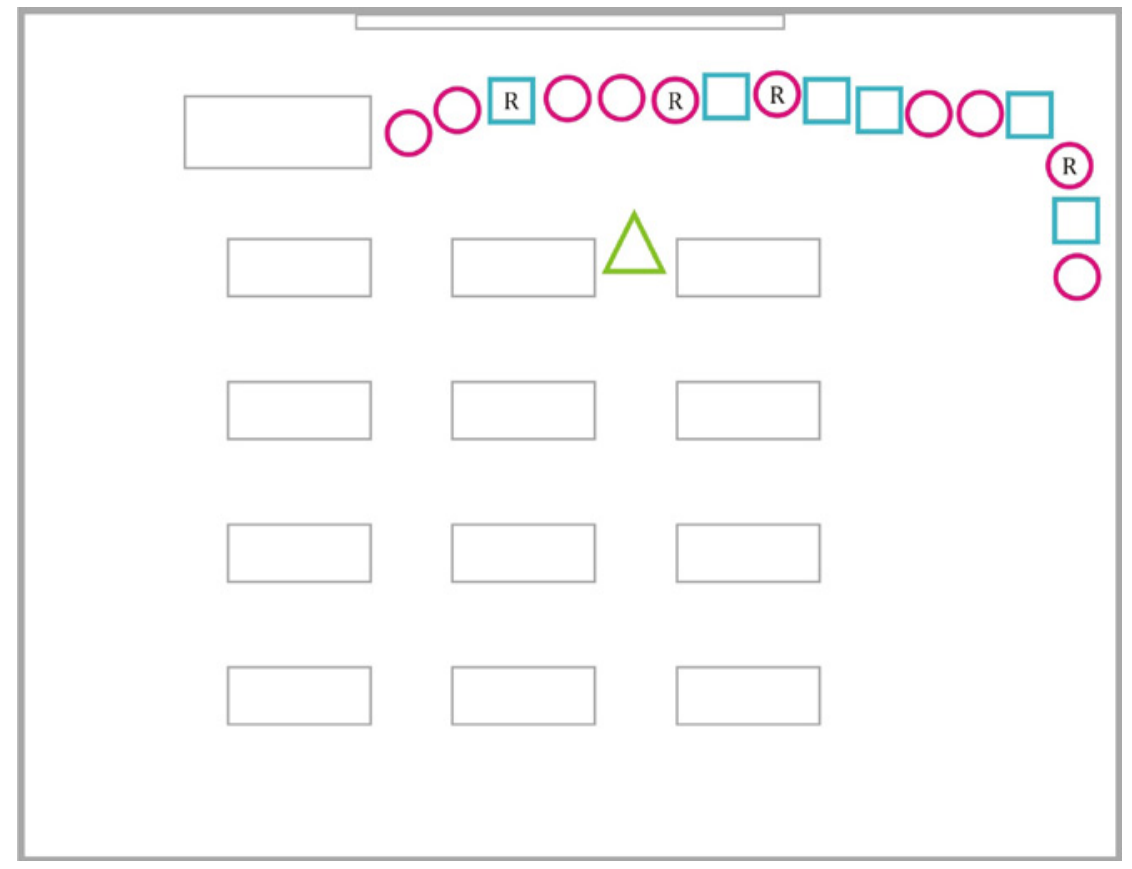

Obrázek 4 Český jazyk a psací tabule 

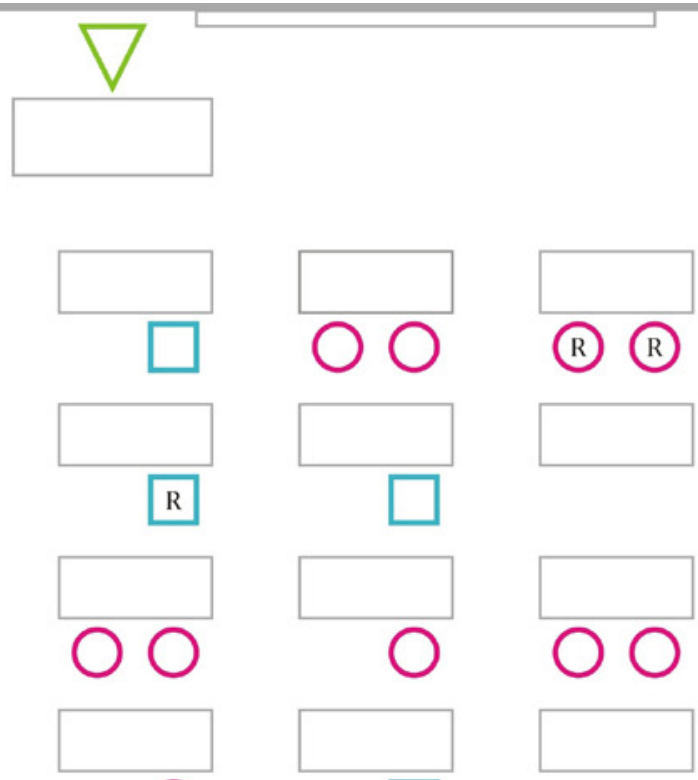

(R)

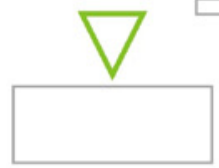

Skupina 2

(R)
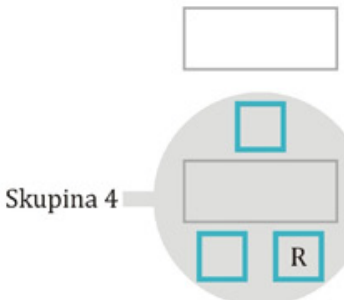

Skupina 4
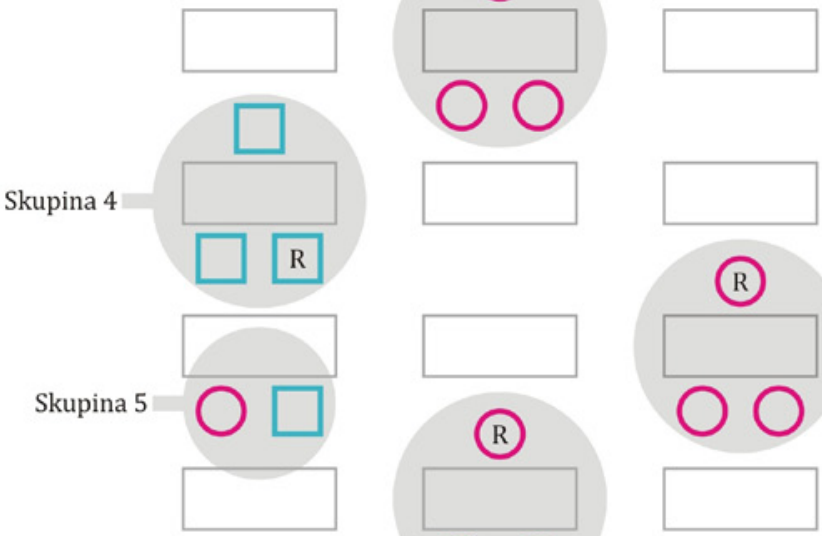

(R)

(R)

Skupina 1
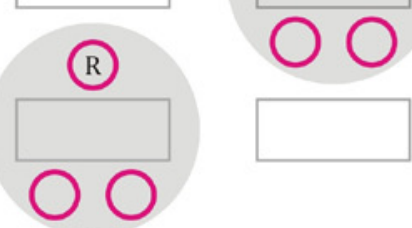

Skupina 3 
Během vyučovací hodiny českého jazyka děti na žádost učitelky vytvářejí trojice a jednu dvojici. V rámci přiděleného cvičení vyhledávají ve skupině slova, která jim zadala učitelka (např. dědeček, naběračka apod.). Dva neromští chlapci míř́ za romským chlapcem a vytvářeji tř́člennou skupinu. Romské divky z prední lavice utvářejí skupiny s neromskými spolužačkami - viz obrázek 5 Zasedací pořádek a vytváření sociálních skupin při vyučovací hodině českého jazyka. (Záznam z pozorování, český jazyk, druhá třída Základní školy Karla Hynka Máchy, 4. 5. 2016.)

\section{Inkluzivní principy třídní učitelky a školního kolektivu}

Během svého výzkumu jsem dospěl k názoru, že děti z druhé třídy si osvojily přístup třídní učitelky a denně ho aplikují o vyučovacích hodinách a přestávkách. Ve většině školních tříd na základních školách, které jsem navštívil, naleznete rozdíly v tom, když skupiny vytváŕí učitelka a když je vytvářejí sami žáci. Nicméně v druhé třídě panuje shoda mezi učitelkou a žáky. Třídní učitelka i žáci vytvářejí skupiny naprosto podobně. Princip, podle kterého učitelka vytváří skupiny je totožný s tím, podle kterého žáci vytvářejí skupiny. ${ }^{19}$ Třídní učitelka často pracuje s dětmi skupinově formou různých zábavných her, ve kterých se děti samy rovnoměrně rozmistují. Žáci sami v prostoru své školní třídy nevytvářejí skupiny dívčí a chlapecké, romské a neromské, vzdělanostně úspěšné a neúspěšné, nýbrž skupiny, na nichž je rovnoměrné uspořádání patrné. $Z$ mého pohledu je druhá třída v tomto ohledu typickou ukázkou inkluzivní školní třídy. Školní třída je vedená vynikající třídní učitelkou, která přesvědčivě dokazuje, že ze sociálního hlediska je možné vzdělávat pospolu žáky z různých sociálních, etnických, ekonomických a vzdělanostních skupin.

V jakých souvislostech je možné chápat výše uvedené výsledky? Myslím si, že převládá pět dominantních oblastí: role pedagoga v inkluzivním vzdělávání a v budování sociálního klimatu školní třídy, vyjednávání významu etnicity ve školním prostředí, otázka rovnosti, žákovské diverzity a kvality ve vzdělávání. ${ }^{20}$ Výsledky mého výzkumu ukazují, že role pedagoga je klíčová pro utváření sociálního klimatu školní třídy. Tyto výsledky plně korespondují s informacemi, které podávají další výzkumníci (za všechny např. Hájková a Strnadová 2010: 65). Stejně tak výzkum potvrzuje, že inkluze závisí na pozitivním prrístupu učitelů a jejich profesionálních dovednostech (blíže např. Rýdl 2011: 316). 
Z výzkumu dále vyplývá, že učitelka má významný vliv na vyjednávání významu etnicity ve školním prostředí - blíže k vyjednávání významu etnicity ve škole (Kašparová - Souralová 2014) či na území obce (Abu Ghosh 2010). Přístup třídní učitelky druhé třídy Základní školy Karla Hynka Máchy do jisté míry také souvisí s aspektem rovnosti, o kterém pojednává Moree a Janská (2008: 82): „Jde o to, zda se pedagog k dětem chová tak, aby rovnost demonstroval, nebo zda nerovnost vytváŕí už v základu samotných interakcí.“ Obecněji je možné výsledky výzkumu vnímat jako střípky do debaty, která se týká tématu žákovské diverzity na jedné straně a kvality vzdělávání na straně druhé (blíže Kasíková - Straková 2011). Rovněž je možné se dívat na text jako na ukázku jednoho z možných způsobů, jakými lze zacházet s rozmanitostí žákovské populace v základním vzdělávání. ${ }^{21}$

\section{"Ne etnicita, ale obezita“: sociální vyloučení v páté třídě}

„Kdo je členem skupiny a kdo ne, ovšem není vždy zřejmé, stejně jako není vždy jasné, které typy skupin jsou důležité, a které nikoli. Předpokládat a priori, že etnické příslušnosti jsou důležitější než ostatní, prostě není možné. “(Eriksen 2012: 284)

Základní inkluzivní škola Karla Hynka Máchy deetnizuje interetnické vztahy v kolektivu dětí. Vedení školy společně s pedagogickým sborem svým přístupem a politikou zmenšuje prostor pro aktivizaci etnicity. Etnicita je ve školním prostř̌edí odsouvána na okraj. Nicméně na příkladu páté třídy bych chtěl ukázat, že se do popředí dostávají další faktory, které v určitých chvílích pomáhají vytvářet třecí plochy v kolektivu dětí.

Pátou třídu Základní školy Karla Hynka Máchy navštěvuje čtrnáct žáků. ${ }^{22}$ Mezi nimi je jedna romská dívka. Z výsledků výzkumu vyplývá, že ve školní třídě nedochází k sociálnímu vyčleňování této romské dívky. Naopak přes velkou snahu třídního učitele je z kolektivu vyčleňován neromský žák Mirek, který je občas svými spolužáky „titulován“ přezdívkou „sádlo“.

Mirek se nejvíce od ostatních spolužáků odlišuje tím, že je obézní. Kromě toho má individuální vzdělávací plán a výrazné problémy s učivem. V některých předmětech spolupracuje s přiděleným asistentem pedagoga, jehož přítomnost ve třídě je velmi důležitá, nebot' spolužáci se chovají k Mirkovi odlišně v jeho nepřítomnosti. Spolužáci si nedovolí urážet a zesměšňovat Mirka v přítomnosti asistenta. Asistent utváŕí okolo Mirka symbolickou hranici, která v konečném důsledku pomáhá vytvářet „třídu ve tř́ídě“ (viz obrázek 6 Třída ve třídě). ${ }^{23}$

21 K tématu zacházení s rozmanitostí žákovské populace viz Kasíková - Straková (2011).

22 Ještě před pár lety školní třídu navštěvovalo 27 dětí. „Některé děti odcházely, jiné přicházely, část zůstávala" (třídní učitel páté třídy, 35 let, Základní škola Karla Hynka Máchy).

23 Upozorňuji čtenáře, že na tomto příkladě poukazuji pouze na méně viditelné sociální důsledky, které může mít (za určitých podmínek) přítomnost asistenta pedagoga ve školní třídě. V žádném případě tento příklad nezpochybňuje práci asistentů pedagoga a jejich přínos v oblasti edukace - přínos (i úskalí) práce asistenta pedagoga předkládá např. Uzlová (2010). 


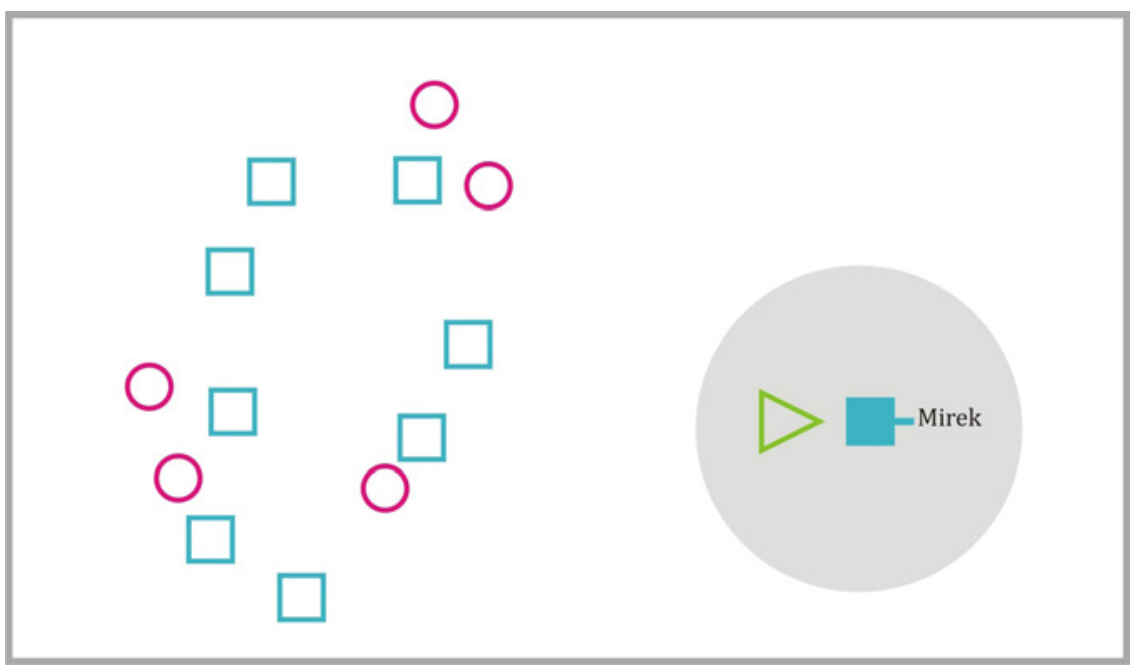

Obrázek 6 Trída ve třídě

Opustí-li ale asistent pedagoga učebnu, situace se mění a pro Mirka nastávají krušnější chvíle. Setkává se s kritickými poznámkami, mířenými na jeho vzhled a obezitu: „Ty jsi tlustej jak bečka sádla“. Kritické vnímání obezity patří k jednomu z nejvýraznějších důvodů, proč spolužáci Mirka zesměšňují a proč ho z některých skupinových aktivit vyčleňují. ${ }^{24}$ „Obézní dítě je vystaveno neúměrnému společenskému tlaku ze strany společensko-estetických norem. Je konfrontováno se šikanou na podkladě anti-fat-rasismu. Je vystaveno pocitu každodenního selhání a sebeobviňování, které vede k depresivním a úzkostným stavům." (Nesrstová - Marinov 2012: 57)

Třídní učitel si uvědomuje problémy spjaté s dětskou obezitou a vnímá obtížnou sociální pozici Mirka v kolektivu dětí. ${ }^{25}$ Snaží se ho začlenit do kolektivu a mírnit dopady sociální exkluze. ${ }^{26}$ „Na čtvrtek bylo naplánované focení s fotografem. Nejprve jsme se všichni vyfotili jako třídní kolektiv a poté se žáci mohli fotit po skupinkách. Bohužel se nikdo nechtěl vyfotit s Mirkem. Přemluvil jsem proto pár žáků, aby se s ním vyfotili. Věděl jsem, že Mirek touží po fotce se svými spolužáky. Chlapci nakonec svolili a vyfotili se s ním.

24 Z mého pozorování vyplývá, že se dívky a chlapci chovají k Mirkovi odlišným způsobem. Mirkovi se nedaří navázat kamarádský vztah zejména s chlapci, protože jsou vůči němu dost kritičtí, zatímco dívky jsou tolerantnější. důraz, aby se děti neposmívaly spolužákům, kteří mají vzdělávací problémy. Mirek byl vyvolán k tabuli. Učitelka mu nadiktovala př́iklad: „Sedm celých dvacet osm děleno třemi“ $(7,28: 3)$. Mirek místo desetinné čárky napsal symbol: „_". Tři chlapci se okamžitě nahlas začali smát. Učitelka na jejich smích zareagovala následovně: „Lukáš, Vojta a Filip, máte 5 př́ikladů navíc. To je to nejhorší, co můžete udělat, posmívat se spolužákovi.“ 
Když ale došlo na objednávání pořízených fotografií, tak si žádný z nich společnou fotku s Mirkem u fotografa neobjednal.“ (třídní učitel páté třídy, 35 let, Základní škola Karla Hynka Máchy)

Antipatie vůči Mirkovi se projevovaly obzvláště při skupinových hrách o volnějších vyučovacích hodinách či o přestávkách. Například při vyučovací hodině českého jazyka v posledních dvaceti minutách děti hrály hru „městečko Palermo“. ${ }^{27}$ Děti se střídaly v roli vypravěče. Jednou se stal vypravěčem i Mirek, ale jeho působení skončilo dříve, než začalo. Téměř polovina žáků nejprve odmítla hrát. Mirek se snažil hru „rozeběhnout“ s druhou půlkou žáků, ale hra po pár minutách zkolabovala díky kritickým poznámkám nehrajících žáků. Mirek si sednul do lavice a na jeho místo nastoupil nový vypravěč. Nehrající žáci se opět zapojili do hry.

Mirek je svými spolužáky odsouván na okraj kolektivu. Marginalizace se projevuje obzvláště během utváření sociálního prostoru v učebnách, kde není dodržován třídním učitelem stanovený zasedací pořádek. Při hodině čtení ve speciální učebně si žáci odsedali dál od Mirka. Nikdo si nepřisednul $\mathrm{k}$ jeho stolu, kde seděl společně $s$ asistentem pedagoga (viz obrázek 7 Čtení ve speciální učebně).

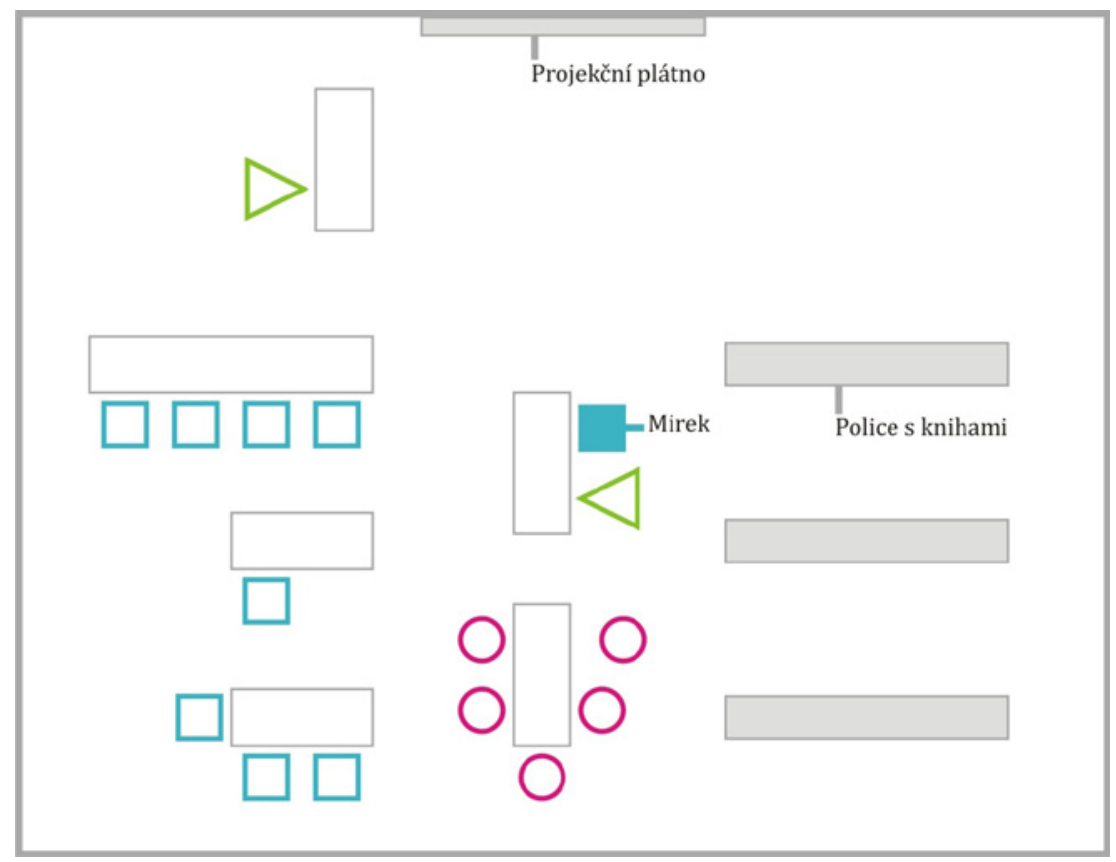

Obrázek 7 Čtení ve speciální učebně

27 Městečko Palermo je známá hra, jejiž princip je vysvětlen na internetových stránkách, které propagují dětské hry (např. www.hranostaj.cz). 


\section{Závěr}

Analýzou Základní školy Karla Hynka Máchy dospívám k závěru, že politika základní školy má významný vliv na podobu sociálních a interetnických vztahů. Víra v myšlenky a hodnoty inkluze se předává z generace učitelů na generaci žáků. Z výzkumu vyplývá, že pro dynamiku inkluze a exkluze v kolektivu dětí je podstatný přístup třídního učitele i dalších členů pedagogického sboru.

Škola učí žáky toleranci a (do jisté míry možná i nevědomky) tím upevňuje vztahy mezi romskými a neromskými žáky. Deetnizuje sociální a interetnické vztahy v kolektivu dětí. Minimalizuje antagonismy v rovině etnické, ale všem konfliktům, odehrávajícím se i v jiných dimenzích, zabránit nedokáže (otázkou zůstává, zda by to bylo vůbec žádoucí).

Lucie Jarkovská dospívá k závěru, že „etnické minority jsou pro české školy akceptovatelné pouze tehdy, pokud jsou neviditelné a neslyšitelné, pokud dokážou přiměřeně splynout a nenarušovat homogenitu“ (Jarkovská 2015: 228). Na základě svých empirických zkušeností se domnívám, že tato teze platí pro velkou část základních škol. Zároveň si ale myslím, že je přehnané zobecňovat toto tvrzení na všechny školy. Můj výzkum ukazuje, že inkluzivní základní školy a základní školy rodinného typu akceptují a začleňují i ty žáky, kteří jsou, jak říká Jarkovská, viditelně a slyšitelně odlišní.

Článek také poukazuje na rozdílné vnímání inkluze uvnitř pedagogického sboru. Někteří učitelé zdůrazňují myšlenku, že každý žák by se měl snažit dosáhnout svého maxima a že každý žák může být úspěšný. Jedním z cílů školy tak je, aby se snažila ze všech žáků dostat maximum. Oproti tomu jiní pedagogové jsou přesvědčeni o tom, že inkluze má za následek, že se po žácích nechce maximum a že zvolený přístup školy je demotivující.

\section{Leden 2018}

\section{Literatura}

Abu Ghosh, Yasar. 2010. „Crediting Recognition. Monetary Transactions of Poor Roma in Tercov." In: Stewart, Michael - Rövid, Márton (eds.): Multi-disciplinary Approaches to Romany Studies. Budapest: Central European University: 91-107.

Bittnerová, Dana - Doubek, David - Levínská, Markéta. 2011. Funkce kulturních modelů ve vzdělávání. Vyd. 1. Praha: Univerzita Karlova, Fakulta humanitních studií.

Bogardus, Emory S. 1925. „Measuring Social Distances“. Journal of Applied Sociology 9: 299-308.

Bogardus, Emory S. 1933. „A Social Distance Scale“. Sociology and Social Research 17: 265-271.

Bogardus, Emory S. 1959. Social Distance. Yellow Spring, OH: The Artichild Press. Booth, Tony - Ainscow, Mel. 2007. Ukazatel inkluze: Rozvoj učení a zapojení ve školách [online]. Redakce a produkce výroby pro CSIE Mark Vaughan. Rytmus, o. s. [2011-02-15] Dostupné z: www.ferovaskola.cz/data/downloads/Index_inkluze.pdf. 
Bryman, Alan. 2012. Social research methods. n. p.: Oxford, New York: Oxford University Press.

ČOSIV. 2015. Česká republika na cestě ke společnému vzdělávání. Zpracoval Jan Klusáček, výzkumný pracovník Lumos, analytik České odborné společnosti pro inkluzivní vzdělávání. Projekt podpořila Nadace Open Society Fund Praha.

EDUin, o. p. s. - Perfect Crowd. 2013. Postoje veřejnosti k českému školství (Srovnání obecná a odborná veřejnost). [2015-10-24] Dostupné z: http://slideplayer.cz/slide/2454737.

Elšík, Viktor. 2005. Romové, etnicita a radikální konstruktivisté. [2016-11-26] Dostupné z: http://www.demografie.info/?cz_detail_clanku\&artclID=115.

Emerson, Robert M. - Fretz, Rachel I. - Shaw, Linda L. 1995. Writing Ethnographic Fieldnotes. Chicago: The University of Chicago Press.

Eriksen, Thomas Hylland. 2008. Sociální a kulturní antropologie: príbuzenství, národnostní př́slušnost, rituál. Vyd. 1. Praha: Portál.

Eriksen, Thomas Hylland. 2012. Etnicita a nacionalismus: antropologické perspektivy. Vyd. 1. Praha: Sociologické nakladatelství (SLON).

Falzon, Mark-Anthony (ed.). 2009. Multi-sited Ethnography: Theory, Praxis and Locality in Contemporary Research. Farnham and Burlington: Ashgate.

Fraňková, Slávka - Pařízková, Jana - Malichová, Eva. 2013. Jídlo v životě dítěte a adolescenta: teorie, výzkum, praxe. Vyd. 1. Praha: Karolinum.

GAC, spol. s r. o. 2009. Vzdělanostní dráhy a vzdělanostní šance romských žákyn̆ a žáků základních škol v okolí vyloučených lokalit: sociologický výzkum zaměřený na analýzu podoby a prríčin segregace dětí, žákyň, žáků a mladých lidí ze sociokulturně znevýhodňujícího prostředí [online]. Závěrečná zpráva projektu MŠMT ČR. [2015-02-01] Dostupné z: www.msmt.cz/file/1627_1_1/.

Hájková, Vanda - Strnadová, Iva. 2010. Inkluzivní vzdělávání. Vyd. 1. Praha: Grada. Horská, Viola. 2009. Koučování ve školní praxi. 1. vydání. Praha: Grada.

Hymes, Dell. 1980. Language in education: ethnolinguistic essays. Center for Applied Linguistics. Washington, D. C.: Center for Applied Linguistics.

Jakoubek, Marek. 2004. Romové - konec (ne)jednoho mýtu: tractatus culturo(mo)logicus. Vyd. 1. Praha: BMSS-Start.

Jarkovská, Lucie [et al.]. 2015. Etnická rozmanitost ve škole: stejnost $v$ různosti. Vyd. 1. Praha: Portál.

Kaleja, Martin - Adamus, Petr - Mühlpachr, Pavel - Zezulková, Eva. 2015. Etnografie školy jako edukační realita současnosti. Opava: Slezská univerzita v Opavě, Fakulta veřejných politik v Opavě, Centrum empirických výzkumů.

Kasíková, Hana - Straková, Jana (eds.). 2011. Diverzita a diferenciace v základním vzdělávání. Vyd. 1. Praha: Karolinum.

Kašparová, Irena - Souralová, Adéla. 2014. „Od lokální k cikánské škole“: homogenizace školní třídy a měnící se role učitele. ORBIS SCHOLAE 8 (1): 79-96.

Lábusová, Adéla - Nikolai, Tomáš - Pekárková, Simona - Rendl, Miroslav. 2010. Nemoc bezmocných: lehká mentální retardace. Analýza inteligenčního testu SON-R. Praha: Člověk v tísni, o. p. s.

Lakoff, George. 2006. Ženy, oheň a nebezpečné věci: co kategorie vypovídají o naší mysli. Vyd. 1. Praha: Triáda.

Levinson, Bradley A. - Pollock, Mica. 2011. A companion to the anthropology of education. Chichester, West Sussex; Malden, MA: Wiley-Blackwell.

Lukas, Josef. 2009. Vztahy mezi učiteli a řediteli na základních školách: přehled relevantních výzkumů. Studia paedagogica: časopis Ústavu pedagogických věd FF MU Brno 14 (1): 127-145.

Marcus, George E. 1995. Ethnography in/of the World System: The Emergence of Multi-Sited Ethnography. Annual Review of Anthropology 24: 95-117. 
Marcus, George E. 1998. Ethnography through thick and thin.

Princeton, N. J.: Princeton University Press.

Mareš, Jiří. 1998. Sociální klima školní třídy. Přehledová studie. AŠR ČR a SR, IPPP. [2016-10-24]

Dostupné z: http://www.klima.pedagogika.cz/trida/doc/Mares_Klima_tridy.pdf.

Mead, Margaret. 1972. Coming of age in Samoa: a psychological study of promitive youth for western civilisation. New York: Morrow Quill.

Mills, David - Morton, Missy. 2013. Ethnography in education. Los Angeles, London: Sage [for the] British Educational Research Association.

Moree, Dana - Janská, Iva. 2008. Než začneme s multikulturní výchovou: od skupinových konceptů k osobnostnímu př́stupu. Praha: Člověk v tísni.

Morvayová, Petra. 2010. Děti „All Exclusive“ - Prostředí sociálně vyloučené lokality a jeho vliv na školní (ne)úspěch. In: Svoboda, Z. - Morvayová, P. (a kol.): Schola Excludus. Ústí nad Labem: UJEP: 9-48.

Nesrstová Marie - Marinov, Zlatko. 2012. Psychosociální rizika běžné dětské obezity. In: Marinov, Zlatko - Pastucha, Dalibor a kol.: Praktická dětská obezitologie. Praha: Grada Publishing: 56-57.

Pierides, Dean. 2010. Multi-Sited Ethnography and the Field of Educational Research. Critical Studies in Education 51: 2: 179-195.

Pražská skupina školní etnografie. 1998. První třída: přiloha závěrečné zprávy o řešení grantového projektu GA ČR 406/94/1417 - leden 1997: „Žák v měnících se podmínkách současné školy." n. p.: Praha: Pedagogická fakulta Univerzity Karlovy.

Rýdl, Karel. 2011. Princip inkluze ve výchovně vzdělávacím systému skandinávských zemí. Př́klad Finska. In: Kasíková, Hana - Straková, Jana (eds.): Diverzita a diferenciace v základním vzdělávání. Vyd. 1. Praha: Karolinum: 302-316.

Spindler, George Dearborn. 1963. Education and culture: anthropological approaches. New York: Holt, Rinehart and Winston.

Spindler, George Dearborn. 1974. Education and cultural process: toward an anthropology of education. New York: Holt, Rinehart and Winston.

Spindler, George Dearborn. 2000. Fifty years of anthropology and education 19502000: a Spindler anthology. Mahwah, N. J., London: Lawrence Erlbaum Associates.

Steinbach, Anja. 2004. Soziale Distanz. Ethnische Grenzziehung und die Eingliederung von Zuwanderern in Deutschland. Wiesbaden: VS Verlag für Sozialwissenschaften.

Svoboda, Zdeněk - Říčan, Jaroslav - Morvayová, Petra - Zilcher, Ladislav. 2015. Metodika tvorby strategického plánu pro vytváření inkluzivního prostředí školy. Ústí nad Labem: Pedagogická fakulta Univerzity J. E. Purkyně v Ústí nad Labem. [2017-04-26] Dostupné z: http://inkluze.ujep.cz/cz/ke-stazeni/metodika.html.

Šafr, Jiří. (ed.). 2008. Sociální distance, interakce, relace a kategorizace: alternativní teoretické perspektivy studia sociální stratifikace. 1. vyd. Praha: Akademie věd České republiky, Sociologický ústav.

Tannenbergerová, Monika. 2016. Průvodce školní inkluzí aneb Jak vypadá kvalitní základní škola současnosti? [E-kniha]. Nakladatel: Wolters Kluwer.

Uzlová, Iva. 2010. Asistence lidem s postižením a znevýhodněním: praktický průvodce pro osobní a pedagogické asistenty. 1. vyd. Praha: Portál.

Varvařovský, Pavel. 2012a. Popis metody a výsledky výzkumu etnického složení žáků bývalých zvláštních škol v ČR v roce 2011/2012 [online]. [2016-11-11] Dostupné z: files.cosiv.cz/200000062-7d2fb7e273/Vyzkum_skoly-metoda.pdf.

Varvařovský, Pavel. 2012b. Výzkum veřejného ochránce práv k otázce etnického složení žákủ bývalých zvláštních škol [online]. [2016-11-11] Dostupné z: files.cosiv.cz/200000063-1e00f1eebb/Vyzkum_skoly-zprava.pdf.

Vorlíček, Radek. 2016a. Doučování Romů v neziskové organizaci. Časopis Komenský. Vydává Pedagogická fakulta Masarykovy Univerzity 140 (03): 53-57. 
Vorlíček, Radek. 2016b. „Vy jste dole, my nahoře“: Sociální a etnické hranice v základní škole. Lidé města/Urban People 18 (3): 441-462.

Vorlíček, Radek. 2017a. „Vyvolení, outsideři a Romové“: Selekce žáků v základní škole s výběrovými třídami. Slovenský národopis 65 (1): 26-38.

Vorlíček, Radek. 2017b. „S odlišností se nekamarádíme“: sociální exkluze žáka se speciálními vzdělávacími potřebami. AntropoWebzin 1-2/2017: 21-29.

Vorlíček, Radek. 2017c. „Už nechceme chodit do školy společně s romskými dětmi": segregace v obci a slovenském vzdělávacím systému. Anthropologia integra 8 (1): 45-52. https://doi.org/10.5817/AI2017-1-45.

Vorlíček, Radek. 2017d. „My černí děláme problémy“: ideologie v sociálně vyloučené lokalitě. Časopis Komenský. Vydává Pedagogická fakulta Masarykovy Univerzity 141 (04): 17-21.

Vorlíček, Radek. 2017e. Sociální pozice romského žáka v prestižní základní škole. Lidé města/Urban People 21 (3): 403-422. 